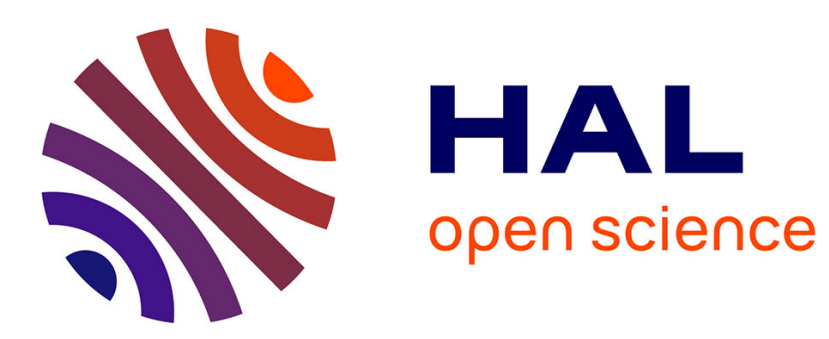

\title{
Using descriptive norm appeals effectively to promote green behavior
}

Leïla Elgaaied-Gambier, Elisa Monnot, Fanny Reniou

\section{To cite this version:}

Leïla Elgaaied-Gambier, Elisa Monnot, Fanny Reniou. Using descriptive norm appeals effectively to promote green behavior. Journal of Business Research, 2018, 82. hal-01630909

\section{HAL Id: hal-01630909 \\ https://hal.science/hal-01630909}

Submitted on 14 Jan 2018

HAL is a multi-disciplinary open access archive for the deposit and dissemination of scientific research documents, whether they are published or not. The documents may come from teaching and research institutions in France or abroad, or from public or private research centers.
L'archive ouverte pluridisciplinaire HAL, est destinée au dépôt et à la diffusion de documents scientifiques de niveau recherche, publiés ou non, émanant des établissements d'enseignement et de recherche français ou étrangers, des laboratoires publics ou privés. 


\section{Using descriptive norm appeals effectively to promote green behavior}

Leila Elgaaied-Gambier ${ }^{\text {a, } 1 \text {, Elisa Monnot }}{ }^{\text {a }}$, Fanny Reniou ${ }^{\text {b }}$

${ }^{\text {a }}$ University of Cergy-Pontoise - Thema (UMR CNRS 8184), 33 boulevard du Port, 95011

Cergy-Pontoise cedex, France

${ }^{\mathrm{b}}$ University of Paris-Est Créteil - IRG (EA 2354), 61 Avenue du Général de Gaulle, 94010

Créteil cedex, France

${ }^{1}$ Corresponding author (Phone number: 00331342522 77)

E-mail addresses: leila.elgaaied@u-cergy.fr (L. Elgaaied-Gambier), elisa.monnot@u-cergy.fr (E. Monnot), fanny.reniou@u-pec.fr (F. Reniou)

This research is part of the Movida research program, funded by the French Ministry of Ecology, Sustainable Development and Energy. 


\title{
Using descriptive norm appeals effectively to promote green behavior
}

\begin{abstract}
Considering that descriptive norm appeals are only effective when they are framed positively, this research investigates the efficacy of such norms in a context in which the prevalent behavior is not environmentally friendly. Using an infomercial promoting purchasing of non-overpackaged products, three studies attempt to manipulate the presence and valence of a descriptive norm, an endorser's presence, and his or her profile. The findings show that triggering a positive descriptive norm results in the adoption of pro-environmental behavior, even when this norm does not reflect the behavior of the majority, provided that consumers perceive the ad as credible. Ad credibility influences intention to avoid overpackaging and, in turn, is influenced by a descriptive norm and a celebrity endorser's profile. The presence of a typical-consumer testimonial, however, influences behavioral intention directly, and the profile of this non-famous endorser influences ad credibility and intention through identification.
\end{abstract}

Keywords: Green behavior; Social norms; Ad credibility; Endorsement; Overpackaging 


\section{Introduction}

Every year, the United Nations hold the Climate Change Conference, which highlights governments' responsibility for adopting pro-environmental regulatory measures to reduce industries' and individuals' ecological footprint. Beyond the implementation of such measures, governments also have a duty to inform and educate the public to adopt an environmentally responsible lifestyle. Among relevant strategies to encourage green behavior, previous research emphasizes the crucial roles of social influence and, in particular, social norms (Goldstein, Cialdini, \& Griskevicius, 2008; Kallgren, Reno, \& Cialdini, 2000; Schultz, 1999).

Social norms refer to "rules and standards that are understood by members of a group, and that guide and/or constrain social behavior without the force of laws" (Cialdini \& Trost, 1998, p. 152). Research indeed acknowledges that social norms influence consumer behavior in general and green behavior in particular, such as intention to purchase sustainable products (e.g., Melnyk, van Herpen, Fischer, \& van Trijp, 2011, 2013). However, to reach optimal effects, advertising should activate two facets of social norms: injunctive norms, which refer to what most people approve of, and descriptive norms, which refer to what people typically do (Cialdini, Reno, \& Kallgren, 1990).

While injunctive norms are usually well understood and are used appropriately, descriptive norms are sometimes employed inadequately, which may lead to counterproductive effects. Cialdini (2003, p. 105) decries advertisers' "tendency to try to mobilize action against a problem by depicting it as regrettably frequent" because doing so can activate a descriptive norm that contradicts the promoted behavior. He provides an example of this advertising practice by describing an anti-littering public service announcement broadcast in the United States in the 1970s and 1980s (i.e. The Iron Eyes Cody spot), but this approach is unfortunately still typical in many countries. In France, for example, the government 
promotes waste reduction by explaining that waste production has doubled in 40 years and that every French citizen currently generates an average of 590 kilos of waste every year ${ }^{1}$. Further, the city of Paris uses a campaign against cigarette littering, stressing that 350 tons of cigarettes butts are discarded every year (to illustrate the message, a picture shows a large pile of cigarette butts on a sidewalk). Although these assertions may be accurate, they implicitly convey that many people are actually adopting these harmful behaviors, indirectly suggesting that littering or producing a large amount of waste is acceptable.

As such, Cialdini (2003) suggests that the valence of social norms should always be positive (i.e., consistent with expected behavior). He thus concludes that priming descriptive norms is only effective when the pro-environmental behavior at stake is predominant among the population. Paradoxically, however, advertising is less critical for pro-environmental practices that the majority already adopts. Governments and other stakeholders engaged in environmental preservation are logically more prone to try to raise awareness of environmentally friendly actions that are not yet widespread. How should campaign developers promote environmentally beneficial behavior using social norms when environmentally harmful behavior is actually prevalent? In this case, should they avoid highlighting descriptive norms? Or can they provide clues about a potential positive descriptive norm (which does not totally reflect reality)?

The general proposition of this research is as follows: when environmentally harmful behavior is prevalent, the use of a positive descriptive norm has a negative effect on perceived ad credibility because the norm does not reflect the behavior of the majority. Nevertheless, this research suggests that such a negative effect on ad credibility can be overcome through certain execution techniques that reinforce the weight of the descriptive norm, in particular through the presence of an endorser. More specifically, this research aims to investigate the circumstances under which descriptive norms can lead to pro-environmental behaviors, 
through the effect of ad credibility. Pro-environmental behaviors refer to "the purchase of environmentally responsible products; products that minimize environmental impact; products from firms with good environmental reputations, or products whose production implies biodegradable, carbon neutral, or recycled inputs" (Grimmer, Kilburn, \& Miles, 2016, p. 1582).

We focus on a particular environmentally friendly behavior, namely the purchasing of non-overpackaged products (e.g., toothpaste tubes without typical cardboard boxes).

Overpackaging refers to outer packaging that surrounds the primary packaging (i.e., the one in direct contact with the product) but, unlike secondary packaging, is not used to gather several units of primary packages (Elgaaied-Gambier, 2016; Monnot, Parguel, \& Reniou, 2015). Because overpackaging uses resources but has no functional purpose (a containing or grouping function), the purchasing of overpackaged products can be deemed an environmentally unfriendly behavior. However, while recycling is becoming a widespread practice in many industrialized countries, consumers are not sufficiently familiar with precycling strategies to reduce household waste. Packaging sustainability also is often reduced to recycling or use of recycled material (Dang \& Chu, 2016), with individuals seemingly less aware of the amount of resources used. In this case, focusing on a less familiar environmental behavior is more appropriate because the informational value of descriptive norm appeals is higher in ambiguous or unfamiliar contexts (White \& Simpson, 2013).

To answer the research questions and test the effect of descriptive norms on ad credibility and intention to purchase non-overpackaged products, three experimental studies manipulate (1) the presence (vs. absence) of a descriptive norm and its valence (positive vs. negative), (2) the presence (vs. absence) of an endorser and his or her similarity (vs. dissimilarity) to the receiver in terms of age, and (3) the type of endorser (celebrity vs. typical consumer) and his or her connection (vs. no connection) with environmental issues. To 
develop the hypotheses, we rely on a broader theoretical background-namely, that of social influence.

\section{Conceptual framework}

\subsection{From social influence theory to social norms theory}

This research relies on social influence theory to identify whether social influence can enhance persuasion in the context of green advertising. In the following paragraphs, we present social influence theory and explain why we focus on the specific concept of social norms within this framework.

\subsubsection{Sub-theories of social influence}

Social influence can be viewed a meta-theory that comprises a network of sub-theories focusing on the study of "change in an individual's thoughts, feelings, attitudes, or behaviors that results from interaction with another individual or a group" (Rashotte, 2007, p. 4426). Although these sub-theories are intertwined, major clusters can be identified.

The first cluster of research highlights the effect of the mere presence of other people on behavior. For example, according to social facilitation and social inhibition theories (Zajonc \& Sales, 1966), individuals tend to perform differently when they are in the presence of others than when they are alone. The second cluster deals with identity issues and includes social comparison theory, identification, and social identity theory. Here, individuals tend to compare themselves with others to determine their opinions and abilities and define their selfconcept (Festinger, 1954). According to social identity theory, individuals' self-concept depends on the groups to which they belong (Tajfel \& Turner, 1979). The third cluster highlights the role of social rules and the processes that lead to compliance-and even obedience if the influence comes from an authority figure (see Milgram, 1965). According to social norms theory (Cialdini et al., 1990; Sherif, 1936), interactions between members of a 
social group lead to the emergence of social rules and standards. When faced with social norms, individuals tend to conform either because they internalized the norm, to gain approval or avoid punishment, or for self-defining purposes (Kelman, 1961). Finally, another significant research cluster is dedicated exclusively to the study of the influence of a specific category of individuals (e.g., celebrities). From a persuasion perspective, the profile and attributes of a celebrity endorser draw attention to the message and transfer image values to the message (Escalas \& Bettman, 2017; Miller \& Allen, 2012; Rudolph, 1947). Furthermore, the image of the celebrity endorser must fit the characteristics of the promoted product or cause (Friedman \& Friedman, 1979; Kamins, 1990). Finally, individuals tend to conform to the attitudes and behaviors of a celebrity endorser when they perceive his or her image as congruent with their ideal self-image (Choi \& Rifon, 2012).

This classification is not exhaustive and some theories fall in several categories or rely on various psychological mechanisms. The dynamic social impact theory (Latané, 1996), for example, is based on the idea that the strength, immediacy, and number of sources of influence determine social influence. The sources of influence are also an important factor to distinguish among the sub-theories. The aforementioned research clusters indeed differ in terms of who exerts the influence. Social influence is likely to emanate from significant others (Wind, 1976), peer and reference groups (Bearden \& Etzel, 1982), authority figures (Milgram, 1965), experts and opinion leaders (Katz \& Lazarsfeld, 1955), celebrities (Atkin \& Block, 1983), and even society as a whole. Although we directly or indirectly use most of the concepts and mechanisms of social influence in this research to justify the hypotheses, we focus mainly on the concept of social norms.

\subsubsection{Building on social influence theory to enhance persuasion: the role of social norms}

We can further categorize studies conducted within the framework of social influence depending on the objective they pursue: (1) identifying the determinants of social influence 
and compliance, (2) uncovering the mechanisms through which social influence operates, and (3) understanding how to use social influence optimally in a persuasion perspective. We ground our work in the third research stream.

Using social influence for persuasion purposes necessitates increasing awareness of the social context and the potential social pressure to adopt the promoted behavior-in our case, an environmentally friendly behavior. One way to achieve this is through the activation of social norms (Cialdini, 2003; Cialdini et al., 1990; Goldstein et al., 2008). Cialdini et al. (1990) show that social norms only affect behavior if they are salient. In other words, advertisers may adopt a strategy geared toward increasing the salience of existing social norms that are favorable to the promoted behavior. They can do so merely by emphasizing the existence of social norms through simple elicitation or personification techniques. Personification generally takes the form of an individual endorsing the message. This person can be either anonymous (a consumer, an employee), or a celebrity (e.g. Fleck, Michel \& Zeitoun, 2014). We test each of these alternative techniques in three studies beginning with simple elicitation of the pro-environmental social norm (Study 1), then adding a typical consumer endorser (Study 2), and, finally, assessing advertising effectiveness in the case of celebrity endorsement (Study 3). Fig. 1 summarizes the different operational perspectives tested in the studies.

Figure 1 here.

\subsection{Impact of social norms on pro-environmental behavior}

Extant literature shows that social norms have a positive impact on sustainable behavior (Cialdini et al., 1990; Goldstein et al., 2008; Melnyk et al., 2011; Reno, Cialdini, \& Kallgren, 1993; Schultz, Nolan, Cialdini, Goldstein, \& Griskevicius, 2007). According to Cialdini et al. (1990), social norms can be either injunctive (i.e., what other people approve or disapprove of) or descriptive (i.e., what most people do). This distinction is important because 
these two dimensions have different effects on the decision-making process. Previous research reveals that injunctive norms exert a stronger impact on attitudes while descriptive norms are a stronger predictor of behavior (Melnyk, van Herpen, \& van Trijp, 2010). This situation is likely because descriptive norms require a simpler cognitive assessment, as they already reflect the behavior of other individuals, which leads consumers to comply more easily with such norms through simple imitation (Cialdini, 2003; Melnyk et al., 2010).

This research focuses on descriptive norms for several reasons. First, this choice is consistent with the objective to examine the impact of social norms when the environmentally beneficial behavior is not prevalent. Second, as mentioned previously, the use of descriptive norms is less well understood and may backfire to produce unwanted effects. Third, describing what most people do introduces injunction (Burchell, Rettie, \& Patel, 2013), while the opposite is not true. Finally, given that descriptive norms have a stronger impact on behavior than injunctive norms (Melnyk et al., 2010), understanding the process through which they affect consumers' decisions offers even more substantial implications for companies, public policy makers or any other organization involved in promoting an environmentally friendly life style. Fig. 2 illustrates the general model of this research and summarizes the hypothesized links for each study.

Figure 2 here.

\subsubsection{Effect of social norms in green advertising: the mediating role of ad credibility}

Previous work highlights the crucial role of ad credibility in attitude formation and behavior (Cotte, Coulter, \& Moore, 2005; Goldberg \& Hartwick, 1990; MacKenzie \& Lutz, 1989). Ad credibility refers to consumers' perceptions that the claims in the ad are true and credible (MacKenzie \& Lutz, 1989). More specifically, the link between ad credibility and purchasing intentions is well documented (Kavanoor, Grewal, \& Blodgett, 1997). Research also investigates the impact of ad credibility on persuasion in the context of pro- 
environmental behavior (Manrai, Manrai, Lascu, \& Ryans, 1997; Newell, Goldsmith, \& Banzhaf, 1998). In the context that consumers are increasingly skeptical about environmental allegations (Do Paço \& Reis, 2012), ad credibility emerges as an important indicator. Previous findings show that an ad perceived as misleading generates a negative attitude and low intention to purchase a green product (Newell et al., 1998).

In line with previous research, ad credibility should positively influence intention to purchase non-overpackaged products. Another assumption is that ad credibility mediates the impact of descriptive norms on intention to purchase non-overpackaged products. By stressing that the majority already adopts the promoted behavior, descriptive norms contribute to enhancing ad credibility. Prior research shows that repetition and familiarity increase the perceived credibility of a statement (Bacon, 1979). One suggested explanation to account for this phenomenon is source dissociation (Arkes, Boehm, \& Xu, 1991). In other words, repetition leads individuals to conclude that they heard the statement from several independent sources, which improves its perceived validity. Research also highlights a "bandwagon effect," according to which the probability to conform increases when the influence emanates from many people (e.g., Granovetter \& Soong, 1986; Latané, 1996). Promoting a behavior by emphasizing its actual adoption by a large number of individuals helps improve the credibility of the message, which in turn affects behavior intent. No research so far examines the link between ad credibility and pro-environmental behaviors when activating a descriptive norm. Thus:

H1. Ad credibility mediates the effect of a descriptive norm pertaining to nonoverpackaged products on intention to purchase non-overpackaged products.

\subsubsection{The moderating role of norm valence}

Melnyk et al. (2013) examine the effects of regulatory focus on descriptive and injunctive norms in the promotion of sustainable products. They show that people perceive 
messages with descriptive norms as more congruent with promotion goals than prevention goals. In contrast with descriptive norms, injunctive norms do not interact with regulatory focus (Melnyk et al., 2013).

Given that the majority of consumers generally do not adopt most pro-environmental behaviors either because they lack information or environmental consciousness or because of the well-documented "attitude-behavior gap" (Grimmer \& Miles, 2017; Kollmuss \& Agyeman, 2002; Moser, 2015; Shaw, McMaster, \& Newholm, 2016), advertisers that want to activate descriptive norms to encourage such behaviors may face counter-productive effects because these norms would be framed negatively. Cialdini (2003, p. 108) notes that "public service communicators should avoid the tendency to send the normatively muddled message that a targeted activity is socially disapproved but widespread." He adds that "norm-based persuasive communications are likely to have their best effects when communicators align descriptive and injunctive normative messages to work in tandem rather than in competition with one another" (p. 108). In other words, to enhance ad effectiveness, both injunctive and descriptive norms must be framed positively (i.e., in favor of the promoted behavior). If the beneficial behavior is not prevalent among the population, a positive descriptive norm is likely to have a negative effect on ad credibility.

H2. Consumers perceive ad credibility as significantly lower (vs. higher) with the activation of a positive (vs. negative) descriptive norm pertaining to non-overpackaged products.

Furthermore, the valence of the descriptive norm should moderate the relationship depicted in H1. The impact of the descriptive norm on behavioral intention through ad credibility likely differs depending on whether the activated descriptive norm is positive or negative. The study thus proposes the following moderated mediation hypothesis:

H3. The valence of the descriptive norm activated in the ad moderates the indirect 
effect of the descriptive norm on intention to purchase non-overpackaged products through ad credibility, such that the indirect effect is stronger (vs. weaker) when the valence of the norm pertaining to non-overpackaged products is positive (vs. negative).

\subsection{Impact of endorsement on ad credibility and pro-environmental behaviors}

As mentioned previously, a positive norm is likely to translate into a proenvironmental behavior but may also lead to a decrease in ad perceived credibility. This research examines the potential effect of endorsement through testimonials to determine how to strengthen ad perceived credibility while activating a positive social norm. A testimonial is a type of endorsement appeal in which an endorser shares his or her experience. Different types of endorsers can appear in advertising campaigns, such as typical consumers or celebrities.

\subsubsection{Typical-consumer testimonials and identification}

Previous studies highlight the impact of social presence on consumer behavior and experience (e.g., He, Chen, \& Alden, 2012). People tend to react differently when they believe they are being observed (Fransen, Smeesters, \& Fennis, 2011). Thus, the presence of other people's testimonials may remind consumers or implicitly suggest to them that others are likely observing their choices.

Using product endorsement with a spokesperson is a common strategy in advertising campaigns (Martin, Wentzel, \& Tomczak, 2008). Previous research shows that infomercial advertising is more effective when including testimonials, expert comments, target market models, or celebrity endorsers (Martin, Bhimy, \& Agee, 2002). Kemp, Min, and Joint (2015) highlight the persuasive power of typical-person testimonials in a health care context. They show that using a typical-consumer testimonial in a rational advertising campaign increases perceptions of trust and usage intentions toward the health care provider. 
Furthermore, Melnyk et al. (2010, p. 463) note that "norms may be more relevant, and hence more influential, when these come from persons with whom the consumer can easily identify." Advertising campaigns often use typical consumers as product endorsers because of their similarity to the message receiver (Ohanian, 1990). The feeling of familiarity that this type of endorser induces has a positive impact on persuasion. Because testimonials enable consumers to imagine the outcome easily, they also help improve consumers' ability to process information presented in the message (Appiah, 2007). The current research argues that the presence of an endorser reinforces ad credibility and stimulates intention to purchase non-overpackaged products.

H4. The presence of an endorser has a positive influence on (a) ad credibility and (b) intention to purchase non-overpackaged products.

This positive effect of typical-consumer endorsement on ad credibility and behavior intention likely occurs through an identification process. Identification theory posits that individuals tend to assess their level of similarity to others and make similarity judgments when they interact (Kelman, 1961). That is, individuals tend to identify with people who share their same characteristics. Thus, according to source-receiver similarity, a testimonial from an endorser is more likely to influence consumers if they view the endorser as similar to themselves (Feick \& Higie, 1992). Among similarity criteria, age of the endorser emerges as a central feature (Huber et al., 2013).

H5. Age similarity between an endorser's profile and the target public profile positively influences (a) ad credibility and (b) intention to purchase non-overpackaged products through the mediator effect of identification with the endorser.

\subsubsection{Connection with environmental issue}

Beyond target similarity criteria, when testing the impact of social influence on behaviors prompted by others, previous work generally takes into account one or several 
intrinsic characteristics of the prompter, such as his or her level of attractiveness (e.g., Kim \& Park, 2011). In particular, previous research highlights the crucial role of endorser credibility on attitude toward the ad and purchase intention (e.g., Lafferty \& Goldsmith, 1999). Given the context of this research, the endorser's legitimacy to promote sustainable action is a relevant criterion to examine. Choosing the right endorser is all the more critical when the decision incurs significant costs, such as in the case of celebrity endorsement.

Using celebrities is a popular advertising technique (Kamins \& Gupta, 1994), and ample research examines the impact of celebrity endorsement. Several studies show that the effectiveness of celebrity endorsement depends on the level of similarity between the endorser and the message (Kamins, 1990; Lynch \& Schuler, 1994). This "matchup" hypothesis indeed seems to generate consensus (Kahle \& Homer, 1985; Kamins, 1990; Till \& Busler, 2000). Although prior research also highlights the potential positive effects of a moderate incongruence between product and celebrity image (Lee \& Thorson, 2008), establishing a link between the object and the endorser is important (Till \& Busler, 2000). According to associative learning theory, the endorser and the product usually match because of "belongingness, relatedness, fit, or similarity" (Till \& Busler, 2000, p. 3). In the specific case of a non-profit context, Wheeler (2009) shows that connection between a celebrity and a nonprofit organization (e.g., American Parkinson Disease Association) is an important variable to consider. According to Wheeler's findings, consumers perceive a celebrity who fits well with the organization as more credible than a non-connected celebrity or a connected average person. In addition, Wheeler (2009) shows that source credibility generated by the connected celebrity has a direct impact on intention to volunteer time and donate money. In the case of pro-environmental behaviors, the presence of a celebrity connected with the environmental issue is likely to influence ad credibility and intention to purchase non-overpackaged products. 
H6. (a) Ad credibility and (b) intention to purchase non-overpackaged products are higher (vs. lower) when the testimonial comes from a celebrity connected with the environmental issue than when the testimonial comes from a non-connected celebrity or a typical consumer.

Three different studies test the hypotheses.

\section{Study 1: Impact of presence and valence of a descriptive norm on ad credibility and behavioral intention}

\subsection{Method}

\subsubsection{Procedure and sample}

This study relies on an experimental design that manipulates the presence and valence of a descriptive norm. The creation of an infomercial inspired by existing advertisements by the French Ministry of Ecology, Sustainable Development and Energy emerged as the most relevant approach. Participants were told that this public service ad was published recently in several newspapers. At the top of the page, the infomercial displays a few lines priming a (positive or negative) descriptive norm and urges people to stop purchasing overpackaged products. At the bottom-left corner of the page, an informative section explains the difference between secondary packaging and overpackaging.

A professional market research agency collected the data online among a diversified sample of the French population. The sample consists of 145 individuals equally distributed among the experimental groups. The sample frame comes from a consumer panel consisting of more than 450,000 individuals living in France. The participants were randomly redirected to one the three experimental conditions (absence of descriptive norm, presence of positive descriptive norm, and presence of negative descriptive norm). The total sample contains $58.6 \%$ men and $41.4 \%$ women. The average age is 45.3 years $(\mathrm{SD}=13.4$; $\operatorname{Min}=19$; $\operatorname{Max}=$ 
65). No significant differences are observed among the groups in terms of gender $\left(\chi^{2}=0.181\right.$; $d f=2 ; p=0.913)$, age $(F=0.747 ; p=0.476)$, socio-professional category $\left(\chi^{2}=27.982 ; d f=\right.$ $22 ; p=0.176)$, or place of residence $\left(\chi^{2}=2.938 ; d f=8 ; p=0.938\right)$.

\subsubsection{Measurement scales}

Manipulation checks include the following: "This ad describes the practices of French people in terms of waste management," "This ad claims that French people are decreasing their household waste," and "This ad claims that the purchase of non-overpackaged products is a growing practice in France." We measure ad credibility with three items adapted from MacKenzie and Lutz (1989). We assess intention to purchase non-overpackaged products with a single item ("In the future, how likely are you to choose non-overpackaged rather than overpackaged products?”). We measure environmental concern, used as a control variable, with Kilbourne and Pickett's (2008) six-item scale. All answers are collected on a 7-point Likert scale ranging from 1 "totally disagree" to 7 "totally agree" except for intention to purchase non-overpackaged products (1 "not at all likely" to 7 "very likely").

We carried out a confirmatory factor analysis to estimate the measurement model (Anderson \& Gerbing, 1988). The analysis did not include intention to purchase nonoverpackaged products, which was captured by a single item. The results are displayed in table 1.

Table 1 here.

\subsection{Results}

Manipulation checks show that participants correctly perceive the presence and valence of the descriptive norm. When the norm is activated, participants indeed associate the advertisement more positively with a description of the practices and habits of French people in terms of waste management $(t=-2.857 ; p<0.01)$. As expected, statements related to the decrease of household waste receive significantly higher scores when the ad displays a 
positive (vs. negative) norm $(t=-7.862 ; p<0.001)$. The results show that perceived ad credibility varies significantly across the experimental conditions $(F=4.31 ; p=0.015)$. Specifically, multiple comparison tests show that when the norm is positive, ad credibility is lower than when the norm is negative (mean difference $=-0.61 ; p=0.027$ ) but is also significantly lower than when the norm is not primed at all (mean difference $=-0.58 ; p=$ 0.039). Thus, $\mathrm{H} 2$ is supported.

In line with prior recommendations to test mediation and moderation effects simultaneously (e.g., Edwards \& Lambert, 2007; Preacher, Rucker, \& Hayes, 2007), we examine the conditional indirect effect of a perceived descriptive norm on behavior intent through ad credibility depending on norm valence, through a single moderated mediation test. $\mathrm{H} 1$ refers to the mediation effect and $\mathrm{H} 3$ to the moderated mediation, so we test $\mathrm{H} 3$, which includes H1, directly. We use Hayes's (2013) PROCESS macro (model 7) to estimate firststage moderated mediation with a $95 \%$ bootstrap confidence interval (CI) based on 10,000 bootstrap samples. Table 2 reports the results.

Table 2 here.

As Table 2 shows, gender, age, and environmental concern serve as covariates. Prior research shows that consumers' socio-demographic profiles (e.g., Granzin \& Olsen, 1991) and level of environmental consciousness (e.g., Kilbourne \& Pickett, 2008) may influence their environmental behavior. The current results reveal no effect of gender but a significant effect of age on behavior intent $(95 \% \mathrm{CI}=0.004,0.041)$ and a significant effect of environmental concern on both ad credibility and intent $(95 \% \mathrm{CI}=0.159,0.558$ and $0.336,0.789$, respectively). The main hypothesized effects remain significant even after we control for these variables.

The results show that the perception of a descriptive norm has a positive influence on ad credibility $(95 \% \mathrm{CI}=0.059,0.316)$ as the confidence interval does not include zero, but 
not on intention $(95 \% \mathrm{CI}=-0.037,0.248)$. The interaction between the perceived descriptive norm and the valence of the norm also influences ad credibility positively $(95 \% \mathrm{CI}=0.088$, 0.586). Perceived ad credibility in turn exerts a significant effect on intention to purchase nonoverpackaged products $(95 \% \mathrm{CI}=0.197,0.620)$. The results also show that the indirect effect of the descriptive norm on intention to purchase non-overpackaged products through ad credibility is only significant when the norm is positive $(95 \% \mathrm{CI}=0.048,0.301)$. Thus, $\mathrm{H} 1$ is partially supported. Finally, the index of moderated mediation (i.e., the slope of the linear function expressing the indirect effect of $\mathrm{X}$ on Y through the mediator; Hayes, 2015) is also significant $(95 \% \mathrm{CI}=0.027,0.314)$, confirming that the valence of the norm moderates the indirect effect of the descriptive norm on intent. Thus, H3 is supported.

\subsection{Study 1 discussion}

Study 1 shows that ad credibility, which itself is influenced by the descriptive norm, influences intention to purchase non-overpackaged products, and descriptive norm valence moderates this process. Specifically, consumers perceive ad credibility as significantly lower when a positive (vs. negative) descriptive norm pertaining to non-overpackaged products is activated. Yet, as mentioned previously, advertisers must use a positive descriptive norm to be consistent with the injunctive norm (Cialdini, 2003). As such, exploring how to enhance ad credibility when a positive descriptive norm is activated would be worthwhile. We thus examine in the next two studies the effect of an endorsement appeal on to strengthening ad credibility and, thereby, behavioral intention. Does the use of an endorser really improve ad credibility and intention to purchase non-overpackaged products? If so, what type of endorser would be appropriate? Study 2 examines the effects of typical consumer endorsement and perceived similarity on ad credibility and intention to purchase non-overpackaged products. 


\section{Study 2: Impact of endorser and identification with the endorser on ad credibility and behavioral intention}

\subsection{Method}

\subsubsection{Procedure and sample}

Study 2 uses the same approach as in Study 1. The experimental design manipulates the presence (vs. absence) of an endorser in the advertisement and his similarity (vs. dissimilarity) to the receiver in terms of age. The same infomercial as in Study 1 now includes a testimonial with a picture of a person and a quotation saying, "I try more and more to be careful about what I buy. Whenever I can, I avoid overpackaged products.” Below the picture are the name and age of the endorser (cf. appendix 1). To manipulate the endorser's similarity, Study 2 exclusively used a sample of young adults $(n=173)$. One of the endorsers was presented as a 22-year-old student (similarity condition) and the other as a 65-year-old retired person (dissimilarity condition). The sample contains $50.3 \%$ women, and the average age is 22.1 years $(\mathrm{SD}=2.13$, Min $=18, \operatorname{Max}=25)$. As in Study 1 , an online market research company collected the data among individuals living in France. The sample frame comes from the same consumer panel as in Study 1, but we ensured that individuals had not already answered Study 1. The participants were randomly assigned to one of three conditions (absence of an endorser, presence of an endorser who is similar to the target audience, and presence of an endorser who is dissimilar to the target audience). The conditions are counterbalanced, and the distribution of participants in terms of age, gender, and socio-professional category is homogeneous across experimental groups.

\subsubsection{Measures}

We measure intention to purchase non-overpackaged products (single item), ad credibility, and environmental concern with the same scales as in Study 1. We assess identification with the endorser with a six-item scale. Reliability and validity information are 
available in table 1.

\subsection{Results}

Manipulation checks reveal that participants perceive the presence of an endorser correctly $(t=-9.58 ; p<0.000)$. As expected, the perceived similarity to the endorser is also significantly greater when he or she is a 22 -year-old student rather than a 65 -year-old retired person $(t=-13.02 ; p<0.000)$. The results show that neither the presence of an endorser nor his profile has a direct effect on ad credibility (respectively, $t=-0.374 ; p=0.709$ and $t=-$ $0.165 ; p=0.869)$. The presence of an endorser, however, positively influences intentions to purchase non-overpackaged products $(t=-2,647 ; p=0.009)$, while the profile of the endorser has no direct effect on intentions $(t=-1,476 ; p=0.143)$. Thus, $\mathrm{H} 4 \mathrm{~b}$ is supported, but $\mathrm{H} 4 \mathrm{a}$ is rejected.

An analysis of mediation was conducted using PROCESS model 4 (10,000 bootstrap samples). The same covariates as in study 1 were included in the analysis, but only environmental concern appears to have a significant effect on ad credibility $(95 \% \mathrm{CI}=0.295$, 0.618 ) and intention $(95 \% \mathrm{CI}=0.340,0.734)$. Contrary to Study 1 , the effect of age on intention is no longer significant, which is due to the fact that the sample is here composed of same age individuals. The results confirm that the presence of an endorser does not influence intention indirectly through ad credibility (indirect effect $=-0.0001 ; 95 \% \mathrm{CI}=-0.065,0.061$ ) but rather directly $($ direct effect $=0.488 ; 95 \% \mathrm{CI}=0.053,0.924)$. A further mediation analysis (model 4; 10,000 bootstrap samples) shows that the profile of the endorser (similar vs. dissimilar) affects ad credibility, but only indirectly through the activation of identification with the endorser (indirect effect $=0.296 ; 95 \% \mathrm{CI}=0.087,0.605$ ). The profile of the endorser also indirectly influences intention through identification (indirect effect $=0.241 ; 95 \% \mathrm{CI}=$ 0.0065, 0.559). Thus, H5a and H5b are supported. 


\subsection{Study 2 discussion}

The results reveal that the presence of an endorser in an ad has a direct positive influence on intention to purchase non-overpackaged products. In addition, the profile of the endorser (similar vs. dissimilar to target audience) influences ad credibility indirectly through the activation of identification with the endorser. Individuals who identify with the endorser are more likely to regard the ad as credible and to purchase non-overpackaged products. Investigating the profile of an endorser might shed more light on the conditions of effectiveness of an advertising strategy based on endorsement. Study 2 highlights the benefits of a typical consumer endorsement in the context of green advertising, but the question remains about the effect of celebrity endorsement. Is use of celebrities to promote a proenvironmental cause worthwhile? If so, what type of celebrity would be suitable? Study 3 investigates the role of a celebrity's connection with the environmental issue and assesses its influence on ad credibility and intention to purchase non-overpackaged products.

\section{Study 3: Impact of celebrity endorsement and profile of the celebrity on ad credibility and behavioral intention}

\subsection{Method}

\subsubsection{Procedure and sample}

Using the same ad as in Studies 1 and 2, Study 3 compares three conditions varying in terms of the endorser's profile: (1) a non-famous endorser, (2) a famous endorser whose image is connected with the environmental issue, and (3) a famous endorser with no connection with the environmental issue. As data collection took place in a French context, comparing two equally popular French public figures seemed appropriate. The first is the well-known environmental activist Nicolas Hulot. According to a survey (Le Monde, 2011), Hulot best embodies the values of environmentalism in France. The second figure is the actor 
Jean Dujardin, who also has a positive image (Le Parisien, 2014) but has no connection with the environmental issue. In order to assess their connection with environmentalism, we conducted a pre-test among 119 respondents prior to the experiment. Environmental connection was assessed through four items: "This person is associated with ecology"; "This person is known for his commitment to the environment", "When I see this person I immediately think about environmental protection", "This person embodies environmental conservation in France". The results of our pre-test show that Nicolas Hulot's perceived connection with environmentalism is much higher than that of Jean Dujardin $\left(\mathrm{M}_{\text {Hulot }}=6.29\right.$; $\left.\mathrm{M}_{\text {Dujardin }}=1.29 ; \mathrm{t}=38.62 ; \mathrm{p}=0.000\right)$. According to the participants, both endorsers are equally famous (respectively $M=6.56$ and $6.52 ; t=-0.187 ; p=0.852$ ).

For the non-famous endorser condition, an ordinary man of approximately the same age as the two celebrities was chosen. Data collection was conducted online by the same market research company as in Studies 1 and 2 to ensure a random redirection of the participants to the different conditions as well as the homogeneity of the experimental groups in terms of sample size and socio-demographic distribution. The total sample, drawn from the same panel of 450,000 French consumers, contains 159 participants (45.9\% women), and the average age is 44.1 years $(\mathrm{SD}=12.66$, $\mathrm{Min}=19, \mathrm{Max}=65)$. No significant differences are observed among the experimental groups in terms of gender, age, socio-professional category, and place of residence.

\subsubsection{Measures}

Environmental concern, ad credibility and intention are measured with the same scales as in studies 1 and 2. Source credibility is measured with four items adapted from Ohanian (1990) reflecting mainly the expertise facet of the concept. As in Studies 1 and 2, the measurement model was estimated and the convergent and discriminant validities were established (cf. table 1). 


\subsection{Results}

The results show that perceived credibility of the endorser varies strongly among the three experimental conditions $(F=30.85 ; p=0.000)$. Participants perceive Nicolas Hulot, the famous pro-environmental activist, as more credible than the other two endorsers (respectively, mean difference $=1.80 ; p=0.000$ and 2.20; $p=0.000$ ). However, no significant difference is observed between Jean Dujardin's credibility and that of the non-famous endorser (mean difference $=-0.30 ; p=0.55$ ). Similarly, ad credibility also varies significantly among the groups $(F=3.66 ; p=0.028)$. Multiple comparison tests show that the only significant difference is between Nicolas Hulot and Jean Dujardin (mean difference $=0.58 ; p$ $=0.021)$.

The results reveal that celebrity endorsement in itself is not a significant predictor of either ad credibility $(\mathrm{t}=-0.166 ; \mathrm{p}=0.868)$ or behavioral intention $(\mathrm{t}=-0.503 ; \mathrm{p}=0.616)$. However, as mentioned previously, the profile of a celebrity does affect ad credibility significantly. We conducted a mediation analysis using PROCESS model 4 (10,000 bootstrap samples). Again, age, gender, and environmental concern served as covariates. The effect of gender and age on intention is not significant $(\mathrm{p}>0.05)$. Consistent with the results of Studies 1 and 2, environmental concern significantly influences ad credibility $(95 \% \mathrm{CI}=0.254$, 0.642 ) and intention $(95 \% \mathrm{CI}=0.019,0.505)$. When we control for this effect, the results show that the direct impact of the profile of the celebrity on intention to purchase nonoverpackaged products is not significant (direct effect $=0.026 ; 95 \% \mathrm{CI}=-0.473,0.526)$ while the indirect effect through ad credibility is significant (indirect effect $=.326 ; 95 \% \mathrm{CI}=$ $0.034,0.695)$. Thus, H6a is supported, but H6b is rejected.

\subsection{Study 3 discussion}

The presence of a celebrity endorser (vs. a typical consumer) has no significant effect on ad credibility and intention to purchase non-overpackaged products. However, the profile 
of the celebrity (i.e., his or her connection with the environmental issue) has a direct impact on ad credibility and an indirect impact on intention to purchase non-overpackaged products through ad credibility. Table 3 summarizes the supported hypotheses for the three studies.

Table 3 here.

\section{General discussion}

The objective of this research is to provide insights into how to use social influence and in particular descriptive appeals effectively to promote green purchasing behavior. The main contributions of this work are threefold. First, the research explains the impact of descriptive norms in a context in which the promoted green behavior is not predominant. Second, it highlights the central role of ad credibility in the process of persuasion based on descriptive norm appeals. Third, the research exposes the conditions under which endorsement is likely to improve ad credibility and green behavior intention.

\subsection{Theoretical contributions}

In line with the observation that descriptive norms can only result in beneficial behavior when they are framed positively (Cialdini, 2003), this research raises the question of the efficiency of such norms in a context in which the prevalent behavior is not environmentally friendly. Focusing on this particular context is a first contribution of this research. Previous work either tests the effect of descriptive norms in a context in which the promoted behavior is predominant or focuses mainly on injunctive norms. The current findings suggest that triggering a positive descriptive norm can result in the adoption of proenvironmental behavior, even though the norm does not entirely reflect reality, provided that consumers perceive the ad as credible. The second contribution lies in the evaluation of the impact of a social norm on ad credibility. In line with Kelman (1961), we find indeed that credibility is a central variable in the process of social influence. Study 1 shows that the presence of a descriptive norm influences intention to purchase non-overpackaged products 
indirectly, through ad credibility. The valence of the descriptive norm moderates this process. Studies 2 and 3 go further by identifying relevant execution techniques that may positively affect ad credibility, while still focusing on a positive descriptive norm. To enhance credibility, use of an endorser in the ad emerges as a relevant solution, especially if individuals actually identify with him or her. Study 2 shows that the presence of an endorser influences intention directly and that the profile of the endorser (young vs. old) indirectly influences credibility and intention through an identification process. Study 3 provides complementary information by testing the impact of a famous and non-famous endorser, as well as the profile of the famous endorser (connected with the environmental issue vs. not connected). The results reveal that celebrity endorsement in itself is a significant predictor of neither ad credibility nor behavioral intention while the profile of the celebrity does affect ad credibility.

On the whole, by examining the activation of social norms to promote proenvironmental behavior, this research enriches the literature on social influence and, more specifically, social influence-based persuasion. Testing the effect of endorsement in the specific case of pro-environmental behaviors is also a contribution of this research. Most studies on the subject focus on the impact of endorsement on brand image, attitude toward the brand, and purchase intention toward a specific product (Kahle \& Homer, 1985; Kamins \& Gupta, 1994; Lee \& Thorson, 2008; Till \& Busler, 2000). Few studies investigate the efficacy of this advertising technique to promote ecological messages or its effect on ad credibility. Some studies do examine the influence of endorsement credibility on green products usage (Lin \& Chang, 2012) or on intention to buy products made by a non-profit organization (Aaker, Vohs, \& Mogilner, 2010), but they do not take into account the type of endorsement, that is, the profile of the endorser. Similarly, few studies examine the role of celebrity endorsement in the context of green behavior. Wheeler (2009) investigates the impact of 
celebrity endorsement in a non-profit context to assess the effect of the endorser's profile (e.g., connection with advertised issue, credibility, gender), but his research applies to a different context (i.e., intention to volunteer time or donate money to fight against Parkinson's disease). Such behavior is likely to have a direct impact on another individual (by helping treat his or her disease), which holds different implications than pro-environmental behavior. The benefits of ecological behavior for others are generally more long term and less concrete. Finally, by exploring the case of a specific pro-environmental behavior, this research also enriches the scarce literature on overpackaging (Elgaaied-Gambier, 2016; Monnot et al., 2015; Thøgersen, 1999).

\subsection{Implications for companies and public policy makers}

This research holds important implications for advertisers, as they tend to activate descriptive norms inappropriately when the prevalent behavior among the population is environmentally unfriendly. First, companies and public policy makers should bear in mind that a strategy that condemns the prevalence of a harmful behavior to promote the opposite behavior is not effective. Descriptive norms should always be framed positively to be consistent with injunctive norms. Second, campaign designers aiming to trigger descriptive norms in a context in which environmentally friendly behavior is not the mainstream should be careful about ad credibility. This notion is all the more critical in a context of widespread greenwashing and growing skepticism about environmental claims (Matthes \& Wonneberger, 2014). The use of an endorser is one possible solution to enhance ad credibility. If the target public is specific, the endorser should ideally match the characteristics of the target.

The current research can further be assimilated with nudge marketing. A nudge aims to place individuals in a context that encourages them to adopt a specific behavior without coercion (Thaler \& Sunstein, 2008). At stake is not an attitudinal change but a behavioral change. In our case, the activation of a positive descriptive norm serves as a type of nudge 
used to encourage purchasing of non-overpackaged products. This research underscores the conditions under which this strategy might be successful (i.e., when personifying the social norm through an endorser who is perceived as legitimate to encourage pro-environmental behavior). A similar type of nudge could be used at the point of sale. Manufacturers could, for example, include clues on product packaging about the social norm pertaining to overpackaging.

This research also tackles the question of the relevance of celebrity endorsement when promoting sustainable behavior. Minton and Rose (1997, p. 45) argue that "because personal norms are internalized social norms, policymakers should (...) consider using social influence strategies such as celebrity or opinion leader endorsement of environmentally friendly behaviors which appeal to feelings of guilt for noncompliance or enhanced self-esteem for environmental concern in a like manner." However, the findings of this research suggest that resorting to a celebrity endorser to encourage pro-environmental behavior should not be an end in itself. To promote green behavior, advertisers can rely on famous endorsers, provided that their image is associated with environmental preservation. Using a celebrity who has no connection with environmental issues generates the same results as using an anonymous endorser, which is not an effective strategy. This result is not consistent with many previous studies conducted in different contexts that highlight the effectiveness of celebrity endorsement (Kahle \& Homer, 1985; Kamins, 1990; Lynch \& Schuler, 1994; Till \& Busler, 2000). This finding is, however, in line with Wheeler's (2009) conclusions in a non-profit context.

Finally, this research raises an important ethical concern. If an environmentally beneficial behavior is not adopted by the masses, presenting it as a social norm would be morally questionable. Advertisers may consider that the end justifies the means and that this technique is tolerable as long as it is used to foster environmental preservation. However, 
regardless of the noble cause, it is preferable not to use false allegations to maintain ethical integrity. When environmentally friendly behavior is not prevalent, one possible solution to activate descriptive norms without resorting to deceitful claims is to stress positive aspects that are actually true while avoiding emphasizing the negative aspects. For example, stating that most people purchase non-overpackaged products may not be true, while stating that several initiatives are being pursued to reduce packaging waste and that a growing number of consumers are taking this information into account when they shop is accurate. Governments can also resort to public opinion polls to include in their ads the proportion of consumers who are willing to change their behavior and avoid overpackaging. Such an appeal is halfway between injunctive and descriptive norms by reflecting what is approved of while conveying clues about others' behavior.

\subsection{Limitations, future research, and conclusion}

The first limitation of this research lies in its lack of external validity. The findings are specific to the French context and should be generalized with caution. As a European country, France differs from the United States and other industrialized countries in environmental issues. For example, Europeans show stronger awareness of climate change than Americans (Peycheva, Pötzschke, Hall, \& Rattinger, 2014). France also differs from other European Union countries and is often deemed less eco-friendly than Germany. Furthermore, this research deals with a particular type of behavior-namely, purchasing of non-overpackaged products. Future research could replicate the studies in other cultural contexts and with other pro-environmental behaviors, such as recycling or energy conservation. Promoting these behaviors through social norms may trigger different decision-making mechanisms. Ecological behaviors comprehend different realities, and the impact of social norms on their adoption may vary depending on the consumer's level of familiarity with the behavior or the public vs. private context in which they operate. 
Second, we examine only two types of endorsers (typical consumers and celebrities). Other types of endorsers could include, for example, non-famous activists or field experts (e.g., environmental scientists, packaging designers), which would help categorize the effect and mechanisms of influence depending on the source type. In addition, this research does not take into account certain potentially relevant variables. For example, individual predispositions, such as consumers' level of susceptibility to normative influence or social comparison tendencies, are likely to play an important role in the process. Similarly, future research could investigate other manipulated variables in complementary experiments. For example, the manipulation of the endorser's similarity to the receiver could include variables other than age, starting with other sociodemographic characteristics such as gender. Research could also test different formulations of the message (e.g., an assertive message) to identify the most appropriate way to activate social norms; in the fictional infomercial developed for the purpose of the current studies, the testimonial was quite neutral. Furthermore, future research could examine whether the way the endorser addresses the receiver (injunction vs. non-assertive testimonial) influences intention to adopt pro-environmental behavior. Prior research examines this question of message wording in the context of green advertising (e.g., Kronrod, Grinstein, \& Wathieu, 2012; Tae Hyun, Sukki, \& Seeun, 2015), but this question is all the more crucial when analyzing the impact of an endorser's profile. How would consumers react if the celebrity not only testifies about his or her own behavior but also urges them to change their conduct (e.g., "You have to stop purchasing overpackaged products")? In conclusion, social influence theory proves helpful in identifying effective ways to enhance persuasion. Researchers need to find new means to translate sub-theories of social influence (and other theories from other fields) into practical insights for marketers and public policy makers. In line with an important stream of literature, this research attempted to increase awareness of the social context by stressing the salience of social norms and, more 
specifically, descriptive norms. However, research needs to test other approaches in the specific context of pro-environmental advertising (e.g., increasing the salience of the social consequences of the behavior with regard to the social norm). Instead of simply underscoring the existing social norm, this alternative approach would emphasize potential reactions of the direct and indirect social network by stressing the positive social consequences in the case of compliance (social reward) or the negative social consequences in the case of non-compliance (social risk). Although these approaches are used for non-profit purposes, taking advantage of people's perceived social pressure and potentially insecure relationships with others to shape their behavior is questionable. Further reflection on the ethical aspects of persuasion techniques based on social influence is also necessary. 


\section{References}

Aaker, J., Vohs, K., \& Mogilner, C. (2010). Non-profits are seen as warm and for-profit as competent: Firm stereotypes matter. Journal of Consumer Research, 37(2), 224-237.

Anderson, J. C., \& Gerbing, D. W. (1988). Structural equation modeling in practice: A revisited and recommended two-step approach. Psychological Bulletin, 103(3), 411423.

Appiah, O. (2007). The effectiveness of 'typical-user' testimonial advertisements on black and white browsers' evaluations of products on commercial websites: Do they really work? Journal of Advertising Research, 47(1), 14-27.

Arkes, H. R., Boehm, L.E., \& Xu, G. (1991). Determinants of judged validity. Journal of Experimental Social Psychology, 27(6), 576-605.

Atkin, C., \& Block, M. (1983). Effectiveness of celebrity endorsers. Journal of Advertising Research, 23(1), 57-61.

Bacon, F. T. (1979). Credibility of repeated statements: Memory for trivia. Journal of Experimental Psychology: Human Learning and Memory, 5, 241-252.

Bearden, W. O., \& Etzel, M. J. (1982). Reference group influence on product and brand purchase decisions. Journal of Consumer Research, 9(2), 183-194.

Burchell, K., Rettie, R., \& Patel, K. (2013). Marketing social norms: Social marketing and the “social norm approach". Journal of Consumer Behaviour, 12(1), 1-9.

Choi, S. M., \& Rifon, N. J. (2012). It is a match: The impact of congruence between celebrity image and consumer ideal self on endorsement effectiveness. Psychology \& Marketing, 29(9), 639-650.

Cialdini, R. B. (2003). Crafting normative messages to protect the environment. Current Directions in Psychological Science, 12(4), 105-109.

Cialdini, R. B., Reno, R. R., \& Kallgren, C. A. (1990). A focus theory of normative conduct: 
Recycling the concept of norms to reduce littering in public places. Journal of Personality and Social Psychology, 58(6), 1015-1026.

Cialdini, R. B., \& Trost, M. R. (1998). Social influence: Social norms, conformity and compliance. In D. T. Gilbert, S. T. Fiske, \& G. Lindzey (Eds.), The handbook of social psychology (Vol. 2, pp. 151-192). New York: McGraw-Hill.

Cotte, J., Coulter, R. A., \& Moore, M. (2005). Enhancing or disrupting guilt: The role of ad credibility and perceived manipulative intent. Journal of Business Research, 58(3), 361-368.

Dang, S., \& Chu, L. (2016). Evaluation framework and verification for sustainable container management as reusable packaging. Journal of Business Research, 69(5), 1949-1955.

Do Paço, A. M. F., \& Reis, R. (2012). Factors affecting skepticism toward green advertising. Journal of Advertising, 41(4), 147-155.

Edwards, J. R., \& Lambert, L. S. (2007). Methods for integrating moderation and mediation: A general analytical framework using moderated path analysis. Psychological Methods, 12(1), 1-22.

Elgaaied-Gambier, L. (2016). Who buys overpackaged grocery products and why? Understanding consumers' reactions to overpackaging in the food sector. Journal of Business Ethics, 135(4), 683-698.

Escalas, J.E., \& Bettman, J.R. (2017). Connecting with celebrities: How consumers appropriate celebrity meanings for a sense of belonging. Journal of Adversting, 46(2), 297-308.

Feick, L., \& Higie, R. A. (1992). The effects of preference heterogeneity and source characteristics on ad processing and judgments about endorsers. Journal of Advertising, 21(2), 16-24.

Festinger, L. (1954). A theory of social comparison processes. Human Relations, 7(2), 117- 
140.

Fleck N., Michel, G., \& Zeitoun, V. (2014). Brand personification through the use of spokespeople: An exploratory study of ordinary employees, CEOs, and celebrities featured in advertising. Psychology and Marketing, 31(1), 84-92.

Fransen, M. L., Smeesters, D., \& Fennis, B. M. (2011). The role of social presence in mortality salience effects. Journal of Business Research, 64(1), 29-33.

Friedman, H. H., \& Friedman, L. (1979). Endorser effectiveness by product type. Journal of Advertising Research, 19(5), 63-71.

Goldberg, M. E., \& Hartwick, J. (1990). The effects of advertiser reputation and extremity of advertising claim on advertising effectiveness. Journal of Consumer Research, 17(2), 172-179.

Goldstein, N. J., Cialdini, R. B., \& Griskevicius, V. (2008). A room with a viewpoint: Using social norms to motivate environmental conservation in hotels. Journal of Consumer Research, 35(3), 472-482.

Granovetter, M., \& Soong, R. (1986). Threshold models of interpersonal effects. Journal of Economic Behavior and Organization, 7, 83-99.

Granzin, K., \& Olsen, J. (1991). Characterizing participants in activities protecting the environment: A focus on donating, recycling, and conservation behaviors. Journal of Public Policy \& Marketing, 10(2), 1-27.

Grimmer, M., Kilburn, A. P., \& Miles, M. P. (2016). The effect of purchase situation on realized pro-environmental consumer behavior. Journal of Business Research, 69(5), $1582-1586$.

Grimmer, M. \& Miles, M. P. (2017). With the best of intentions: A large sample test of the intention-behaviour gap in pro-environmental consumer behavior. International Journal of Consumer Studies, 41(1), 2-10. 
Hayes, A. F. (2013). Introduction to mediation, moderation, and conditional process analysis: A regression-based approach. New York: Guilford Press.

Hayes, A. F. (2015). An index and test of linear moderated mediation. Multivariate Behavioral Research, 50(1), 1-22.

He, Y., Chen, Q., \& Alden, D. L. (2012). Consumption in the public eye: The influence of social presence on service experience. Journal of Business Research, 65(3), 302-310.

Huber, F., Meyer, F., Vogel, J., Weihrauch, A., \& Hamprecht, J. (2013). Endorser age and stereotypes: Consequences on brand age. Journal of Business Research, 66(2), 207215.

Kahle, L. R., \& Homer, P. M. (1985). Physical attractiveness of the celebrity endorser: A social adaptation perspective. Journal of Consumer Research, 11(4), 954-961.

Kallgren, C. A., Reno, R. R., \& Cialdini, R. B. (2000). A focus theory of normative conduct: When norms do and do not affect behavior. Personality and Social Psychology Bulletin, 26(8), 1002-1012.

Kamins, M. A. (1990). An investigation into the "match-up" hypothesis in celebrity advertising: When beauty may be only skin deep. Journal of Advertising, 19(1), 4-13.

Kamins, M. A., \& Gupta, K. (1994). Congruence between spokesperson and product type: A matchup hypothesis perspective. Psychology \& Marketing, 11(6), 569-586.

Katz, E., \& Lazarsfeld, P. F. (1955). Personal influence: The part played by people in the flow of mass communications. New York: The Free Press.

Kavanoor, S., Grewal, D., \& Blodgett, J. (1997). Ads promoting OTC medications: The effect of ad format and credibility on beliefs, attitudes, and purchase intentions. Journal of Business Research, 40(3), 219-227.

Kelman, H. C. (1961). Process of opinion change. Public Opinion Quarterly, 25(1), 57-78.

Kemp, E., Min, K. S., \& Joint, E. (2015). Selling hope: The role of affect-laden health care 
advertising in consumer decision making. Journal of Marketing Theory and Practice, 23(4), 434-454.

Kilbourne, W., \& Pickett, G. (2008). How materialism affects environmental beliefs, concern, and environmentally responsible behavior. Journal of Business Research, 61(9), 885893.

Kim, S.-H., \& Park, H. J. (2011). Effects of social influence on consumers' voluntary adoption of innovations prompted by others. Journal of Business Research, 64(11), 1190-1194.

Kollmuss, A., \& Agyeman, J. (2002). Mind the gap: Why do people act environmentally and what are the barriers to pro- environmental behavior? Environmental Education Research, 8(3), 239-260.

Kronrod, A., Grinstein, A., \& Wathieu, L. (2012). Go green! Should environmental messages be so assertive? Journal of Marketing, 76(1), 95-102.

Lafferty, B. A., \& Goldsmith, R. E. (1999). Corporate credibility's role in consumers' attitudes and purchase intentions when a high versus a low credibility endorser is used in the ad. Journal of Business Research, 44(2), 109-116.

Latané, B. (1996). Dynamic social impact: The creation of culture by communication. Journal of Communication, 46(4), 13-25.

Le Monde (2011). Nicolas Hulot première personnalité écologiste, selon un sondage [Nicolas Hulot first environmentalist personality according to a survey]. http://www.lemonde.fr/election-presidentielle-2012/article/2011/11/13/pour-nicolashulot-la-sortie-du-nucleaire-est-un-objectif-moralincontournable_1603101_1471069.html Accessed 10 September 2017.

Le Parisien (2014). Jean Dujardin plébiscité par 8 Français sur 10 [Jean Dujardin praised by 8 out of 10 French]. http://www.leparisien.fr/laparisienne/actupeople/personnalites/jean-dujardin-plebiscite-par-8-francais-sur-10-29-11-2014- 
4333187.php Accessed 10 September 2017.

Lee, J.-G., \& Thorson, E. (2008). The impact of celebrity-product incongruence on the effectiveness of product endorsement. Journal of Advertising Research, 48(3), 433449.

Lin, Y.-C., \& Chang, C.-C. A. (2012). Double standard: The role of environmental consciousness in green product usage. Journal of Marketing, 76(5), 125-134.

Lynch, J., \& Schuler, D. (1994). The matchup effect of spokesperson and product congruency: A schema theory interpretation. Psychology \& Marketing, 11(5), 417445.

MacKenzie, S. B., \& Lutz, R. J. (1989). An empirical examination of the structural antecedents of attitude toward the ad in an advertising pretesting context. Journal of Marketing, 53(2), 48-65.

Manrai, L. A., Manrai, A. K., Lascu, D.-N., \& Ryans, J. K. (1997). How green-claim strength and country disposition affect product evaluation and company image. Psychology \& Marketing, 14(5), 511-537.

Martin, B. A. S., Bhimy, A. C., \& Agee, T. (2002). Infomercials and advertising effectiveness: An empirical study. Journal of Consumer Marketing, 19(6), 468-480.

Martin, B. A. S., Wentzel, D., \& Tomczak, T. (2008). Effects of susceptibility to normative influence and type of testimonial on attitudes toward print advertising. Journal of Advertising, 37(1), 29-43.

Matthes, J., \& Wonneberger, A. (2014). The skeptical green consumer revisited: Testing the relationship between green consumerism and skepticism toward advertising. Journal of Advertising, 43(2), 115-127.

Melnyk, V., van Herpen, E., Fischer, A. R. H., \& van Trijp, H. C. M. (2011). To think or not to think: The effect of cognitive deliberation on the influence of injunctive versus 
descriptive social norms. Psychology \& Marketing, 28(7), 709-729.

Melnyk, V., van Herpen, E., Fischer, A. R. H., \& van Trijp, H. C. M. (2013). Regulatory fit effects for injunctive versus descriptive social norms: Evidence from the promotion of sustainable products. Marketing Letters, 24(2), 191-203.

Melnyk, V., van Herpen, E., \& van Trijp, H. C. M. (2010). The influence of social norms in consumer decision making: A meta-analysis. In M. C. Campbell, J. Inman, \& R. Pieters (Eds.), Advances in consumer research (Vol. 37, pp. 463-464). Duluth, MN: Association for Consumer Research.

Milgram, S. (1965). Some conditions of obedience and disobedience to authority. Human Relations, 18(1), 57-76.

Miller, F. M., \& Allen, C. T. (2012). How does celebrity meaning transfer? Investigating the process of meaning transfer with celebrity affiliates and mature brands. Journal of Consumer Psychology, 22(3), 443-452.

Minton, A. P., \& Rose, R. L. (1997). The effects of environmental concern on environmentally friendly consumer behavior: An exploratory study. Journal of Business Research, 40(1), 37-48.

Monnot, E., Parguel, B., \& Reniou, F. (2015). Consumer responses to elimination of overpackaging on private label products. International Journal of Retail \& Distribution Management, 43(4/5), 329-349.

Moser, A. (2015). Thinking green, buying green? Drivers of pro-environmental purchasing behavior. Journal of Consumer Marketing, 32(3), 167-175.

Newell, S. J., Goldsmith, R. E., \& Banzhaf, E. J. (1998). The effects of misleading environmental claims on consumer perceptions of advertising. Journal of Marketing Theory and Practice, 6(2), 48-60.

Ohanian, R. (1990). Construction and validation of a scale to measure celebrity endorser's 
perceived expertise, trustworthiness, and attractiveness. Journal of Advertising, 19(3), $39-52$.

Peycheva, D., Pötzschke, J., Hall, T. D., \& Rattinger, H. (2014). Attitudes towards environmental issues: Empirical evidence in Europe and the United States. http://www.transworld-fp7.eu/wp-content/uploads/2014/06/TW_WP_31.pdf Accessed 8 September 2017.

Preacher, K. J., Rucker, D. D., \& Hayes, R. F. (2007). Addressing moderated mediation hypotheses: Theory, methods, and prescriptions. Multivariate Behavioral Research, 42(1), 185-227.

Rashotte, L. S. (2007). Social influence. In G. Ritzer \& J. M. Ryan (Eds.), The Blackwell encyclopedia of sociology (pp. 4426-4428). Oxford: Blackwell.

Reno, R. R., Cialdini, R. B., \& Kallgren, C. A. (1993). The transsituational influence of social norms. Journal of Personality and Social Psychology, 64(1), 104-112.

Rudolph, H. (1947). Attention and interest factors in advertising. New York: Printers' Ink.

Schultz, P. W. (1999). Changing behavior with normative feedback interventions: A field experiment on curbside recycling. Basic and Applied Social Psychology, 21(1), 25-38.

Schultz, P. W., Nolan, J. M., Cialdini, R. B., Goldstein, N. J., \& Griskevicius, V. (2007). The constructive, destructive, and reconstructive power of social norms. Psychological Science, 18(5), 429-434.

Shaw, D., McMaster R., \& Newholm, T. (2016). Care and commitment in ethical consumption: An exploration of the "attitude-behaviour gap". Journal of Business Ethics, 136(2), 251-265.

Sherif, M. (1936). The psychology of social norms. New York: Harper.

Tae Hyun, B., Sukki, Y., \& Seeun, K. (2015). When environmental messages should be assertive: Examining the moderating role of effort investment. International Journal 
of Advertising, 34(1), 135-157.

Tajfel, H., \& Turner, J. C. (1979). An integrative theory of inter-group conflict. In W. G. Austin \& S. Worchel (Eds.), The social psychology of inter-group relations (pp. 3347). Monterey, CA: Brooks/Cole.

Thaler, R., \& Sunstein, C. (2008). Nudge: Improving decisions about health, wealth and happiness. New Haven, CT: Yale University.

Thøgersen, J. (1999). The ethical consumer. Moral norms and packaging choice. Journal of Consumer Policy, 22(4), 439-460.

Till, B. D., \& Busler, M. (2000). The match-up hypothesis: Physical attractiveness, expertise, and the role of fit on brand attitude, purchase intent and brand beliefs. Journal of Advertising, 29(3), 1-13.

Wheeler, R. T. (2009). Nonprofit advertising: Impact of celebrity connection, involvement and gender on source credibility and intention to volunteer time or donate money. Journal of Nonprofit \& Public Sector Marketing, 21(1), 80-107.

White, K., \& Simpson, B. (2013). When do (and don't) normative appeals influence sustainable consumer behaviors? Journal of Marketing, 77(2), 78-95.

Wind, Y. (1976). Preference of relevant others and individual choice models. Journal of Consumer Research, 3(1), 50-57.

Zajonc, R. B., \& Sales, S. M. (1966). Social facilitation of dominant and subordinate responses. Journal of Experimental Social Psychology, 2(2), 160-168. 
Fig. 1. Operational perspectives when activating social influence for persuasion purposes

\section{How to use social influence theory to enhance persuasion}

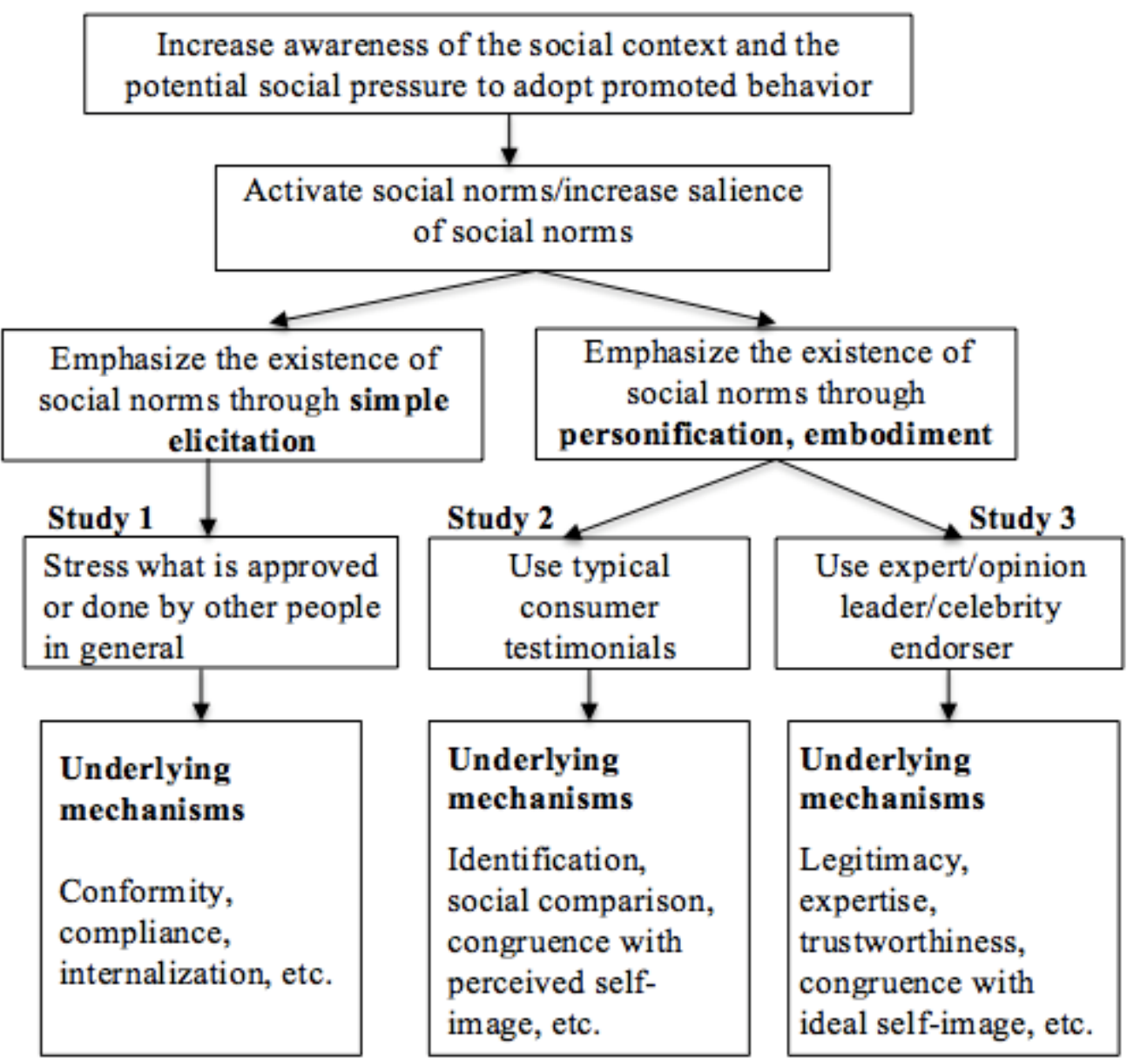


Fig. 2. Conceptual model

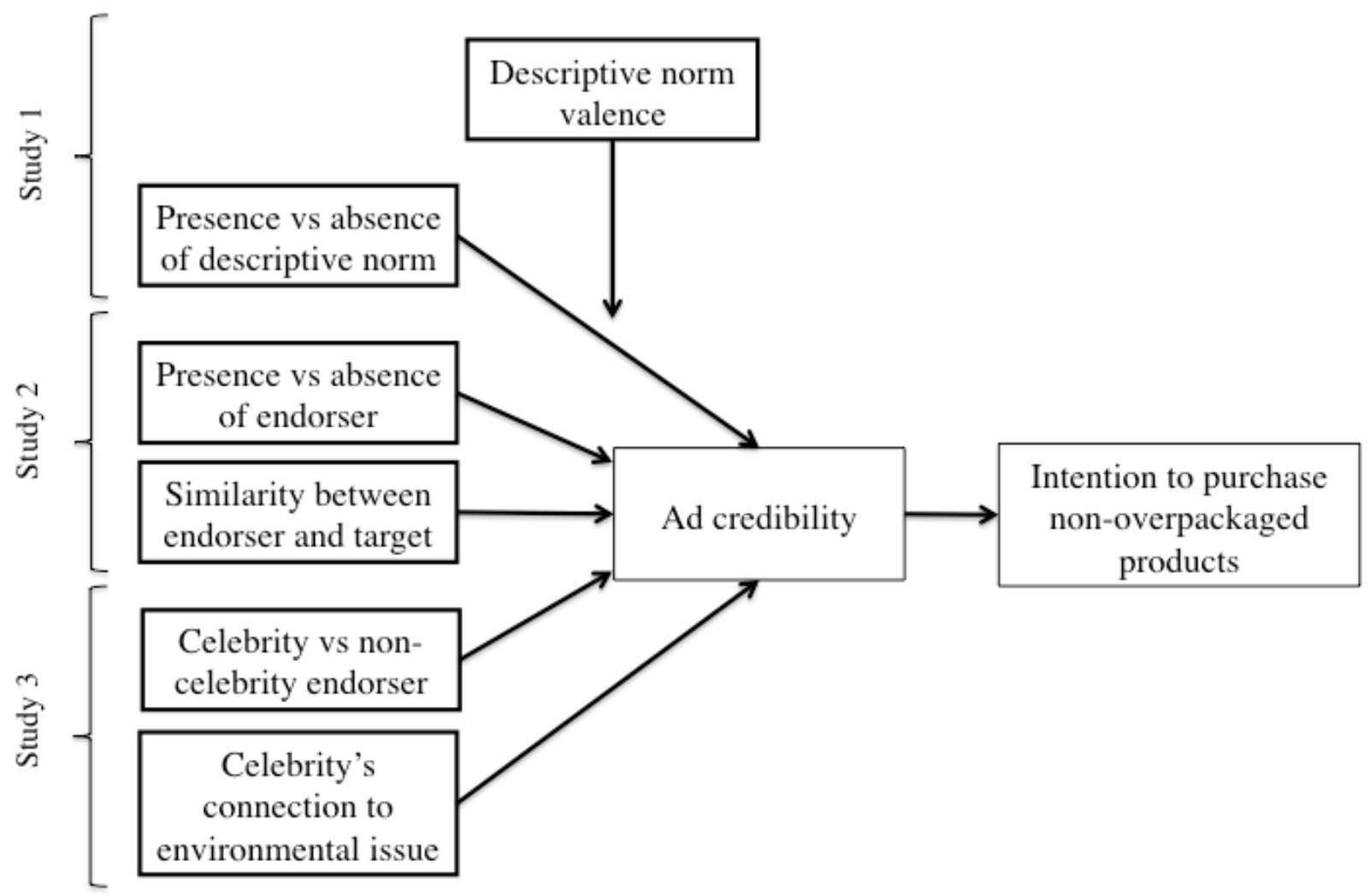


Table 1. Reliability and validity of the measurement scales

\begin{tabular}{|c|c|c|c|c|c|c|c|c|c|}
\hline & \multicolumn{3}{|c|}{ Study $1(n=145)$} & \multicolumn{3}{|c|}{ Study $2(n=173)$} & \multicolumn{3}{|c|}{ Study $3(n=159)$} \\
\hline & $\alpha$ & St. B & AVE & $\alpha$ & St. B & AVE & $\alpha$ & St. B & AVE \\
\hline \multicolumn{10}{|l|}{ Ad credibility } \\
\hline $\begin{array}{l}\text { The allegations presented in this ad } \\
\text { are true }\end{array}$ & \multirow{3}{*}{.940} & .860 & \multirow{3}{*}{.842} & \multirow{3}{*}{.931} & .909 & \multirow{3}{*}{.829} & \multirow{3}{*}{.917} & .875 & \multirow{3}{*}{.787} \\
\hline This ad is unbiased & & .932 & & & .934 & & & .898 & \\
\hline $\begin{array}{l}\text { I believe the claims presented in this } \\
\text { ad }\end{array}$ & & .958 & & & .888 & & & .888 & \\
\hline \multicolumn{10}{|l|}{ Environmental concern } \\
\hline $\begin{array}{l}\text { I am very concerned about the } \\
\text { environment }\end{array}$ & \multirow{7}{*}{.916} & .799 & \multirow{7}{*}{.638} & & .746 & \multirow{7}{*}{.655} & & .789 & \multirow{7}{*}{.542} \\
\hline $\begin{array}{l}\text { Humans are severely abusing the } \\
\text { environment }\end{array}$ & & .799 & & & .778 & & & .823 & \\
\hline $\begin{array}{l}\text { I would be willing to reduce my } \\
\text { consumption to help protect the }\end{array}$ & & .893 & & & .874 & & & .757 & \\
\hline environment & & & & .902 & & & .881 & & \\
\hline $\begin{array}{l}\text { Major political change is necessary to } \\
\text { protect the natural environment }\end{array}$ & & .737 & & & .793 & & & .635 & \\
\hline $\begin{array}{l}\text { Major social changes are necessary to } \\
\text { protect the natural environment }\end{array}$ & & .770 & & & .881 & & & .697 & \\
\hline $\begin{array}{l}\text { Anti-pollution laws should be } \\
\text { enforced more strongly }\end{array}$ & & .786 & & & .774 & & & .700 & \\
\hline \multicolumn{10}{|l|}{ Identification with the endorser } \\
\hline I can easily identify with this person & \multirow{6}{*}{-} & - & \multirow{6}{*}{ - } & & .821 & \multirow{6}{*}{.687} & & - & \multirow{6}{*}{-} \\
\hline This person looks like me & & - & & & .961 & & & - & \\
\hline $\begin{array}{l}\text { I feel like I share the same values as } \\
\text { this person }\end{array}$ & & - & & .926 & .915 & & - & - & \\
\hline I feel close to this person & & - & & & .727 & & & - & \\
\hline I feel like I know this person & & - & & & .867 & & & - & \\
\hline I recognize myself in this person & & - & & & .637 & & & - & \\
\hline \multicolumn{10}{|l|}{ Source credibility } \\
\hline \multicolumn{10}{|l|}{$\begin{array}{l}\text { About the subject treated in this } \\
\text { advertisement, the person testifying }\end{array}$} \\
\hline Expert & \multirow{4}{*}{-} & - & & \multirow{4}{*}{ - } & - & \multirow{4}{*}{ - } & & .913 & \multirow{4}{*}{.887} \\
\hline Experienced & & - & & & - & & & .963 & \\
\hline Qualified & & - & & & - & & 969 & .965 & \\
\hline Skilled & & - & & & - & & & .925 & \\
\hline \multirow[t]{2}{*}{ Discriminant validity check } & \multicolumn{3}{|c|}{$\begin{array}{c}\text { Correlation between ad } \\
\text { credibility and } \\
\text { environmental concern } \\
.385 \text { (Squared correlation } \\
<\text { AVEs) }\end{array}$} & $\begin{array}{l}\text { Corre } \\
\text { betwe } \\
\text { (Squar }\end{array}$ & $\begin{array}{l}\text { lations ra } \\
\text { n .383 at } \\
\text { d correl } \\
\text { AVEs) }\end{array}$ & $\begin{array}{l}\text { nging } \\
\text { d .429 } \\
\text { tions }<\end{array}$ & $\begin{array}{l}\text { Corr } \\
\text { betwe } \\
\text { (Squar }\end{array}$ & $\begin{array}{l}\text { ations } r \\
\text { n.299 a } \\
\text { d correl } \\
\text { AVEs) }\end{array}$ & $\begin{array}{l}\text { ging } \\
\text { d.506 } \\
\text { tions }<\end{array}$ \\
\hline & $\begin{array}{r}\chi^{2} / \mathrm{df}= \\
\mathrm{CFI}= \\
.063, \mathrm{G}\end{array}$ & $\begin{array}{l}\text { 57, TLI } \\
86, \text { RMS } \\
\text { I }=.948, \\
=.034\end{array}$ & $\begin{array}{l}.979 \\
\text { EA }= \\
\text { SRMR }\end{array}$ & $\begin{array}{r}\chi^{2 / \mathrm{df}}= \\
\mathrm{CFI}= \\
.08 \\
\mathrm{SH}\end{array}$ & $\begin{array}{l}1.74, \mathrm{TLI} \\
957, \mathrm{RM} \\
\mathrm{GFI}=. \\
\mathrm{MR}=.0\end{array}$ & $\begin{array}{l}=.946 \\
\text { SEA = } \\
354 \\
76\end{array}$ & $\begin{array}{r}\chi^{2} / \mathrm{df}= \\
\mathrm{CFI}= \\
.07 \\
\mathrm{~S}\end{array}$ & $\begin{array}{l}.86, \mathrm{TL} \\
970, \mathrm{RN} \\
\mathrm{GFI}= \\
\mathrm{MR}=.\end{array}$ & $\begin{array}{l}=.962, \\
\text { SEA = } \\
399, \\
42\end{array}$ \\
\hline
\end{tabular}

Likert format: $1=$ totally disagree; 7 = totally agree; $\alpha$ : Cronbach's alpha; St. B: standard factor loading; AVE: average variance extracted. TLI: Tucker-Lewis index, CFI= comparative fit index, RMSEA: root mean square error of approximation, $\mathrm{GFI}=$ goodness of fit index, SRMR= standardized root mean square residual.

Intention to avoid over-packaged products was excluded from the measurement model as it is measured with a single item. 
Table 2. Conditional indirect effect of descriptive norm on intention to purchase nonoverpackaged products through ad credibility depending on norm valence

\begin{tabular}{|c|c|c|c|c|}
\hline \multirow{3}{*}{ Independent variables } & \multicolumn{4}{|c|}{ Dependent variables } \\
\hline & \multicolumn{2}{|c|}{$\begin{array}{l}\text { Perceived ad } \\
\text { credibility (M) }\end{array}$} & \multicolumn{2}{|c|}{$\begin{array}{l}\text { Intention to purchase } \\
\text { non-overpackaged } \\
\text { products }(Y)\end{array}$} \\
\hline & b (SE) & $95 \% \mathrm{CI}$ & b (SE) & $95 \% \mathrm{CI}$ \\
\hline Perceived descriptive norm & $.19(.06)$ & {$[.059, .316]$} & $.11(.07)$ & {$[-.037, .248]$} \\
\hline $\begin{array}{l}\text { Valence of descriptive } \\
\text { norm }\end{array}$ & $-.57(.22)$ & {$[-1.02, .132]$} & & \\
\hline $\begin{array}{l}\text { Perceived descriptive norm } \\
\times \text { Valence of descriptive } \\
\text { norm }\end{array}$ & $.33(.13)$ & {$[.088, .586]$} & & \\
\hline Perceived ad credibility & & & $.41(.11)$ & {$[.197, .620]$} \\
\hline $\begin{array}{l}\text { Covariates } \\
\text { Environmental concern }\end{array}$ & $.36(.10)$ & {$[.159, .558]$} & $.56(.11)$ & {$[.336, .789]$} \\
\hline Gender & $.09(.23)$ & {$[-.363, .547]$} & $.31(.25)$ & {$[-.182, .808]$} \\
\hline Age & $.01(.01)$ & {$[-.007, .027]$} & $.02(.01)$ & {$[.004, .041]$} \\
\hline $\mathrm{R}^{2}$ & .3 & & .4 & \\
\hline \multicolumn{5}{|c|}{$\begin{array}{c}\text { Conditional indirect effect of } \mathrm{X} \text { on } \mathrm{Y} \text { at values } \\
\text { of the moderator }\end{array}$} \\
\hline Negative descriptive norm & \multicolumn{2}{|c|}{$.01(.03)$} & \multicolumn{2}{|c|}{$[-.057, .082]$} \\
\hline Positive descriptive norm & \multicolumn{2}{|c|}{$.15(.06)$} & \multicolumn{2}{|c|}{$[.048, .301]$} \\
\hline $\begin{array}{l}\text { Index of moderated } \\
\text { mediation }\end{array}$ & \multicolumn{2}{|c|}{$.14(.07)$} & \multicolumn{2}{|c|}{$[.027, .314]$} \\
\hline
\end{tabular}


Table 3. Summary of hypotheses testing

\begin{tabular}{|c|c|c|}
\hline & Hypotheses & Conclusion \\
\hline H1. & $\begin{array}{l}\text { Ad credibility mediates the effect of a descriptive norm } \\
\text { pertaining to non-overpackaged products on intention to } \\
\text { purchase non-overpackaged products. }\end{array}$ & $\begin{array}{l}\text { Partially supported } \\
\text { (only true when } \\
\text { the descriptive } \\
\text { norm is positive) }\end{array}$ \\
\hline H2. & $\begin{array}{l}\text { Consumers perceive ad credibility as significantly lower (vs. } \\
\text { higher) with the activation of a positive (vs. negative) descriptive } \\
\text { norm pertaining to non-overpackaged products. }\end{array}$ & Supported \\
\hline H3. & $\begin{array}{l}\text { The valence of the descriptive norm activated in the ad } \\
\text { moderates the indirect effect of the descriptive norm on intention } \\
\text { to purchase non-overpackaged products through ad credibility, } \\
\text { such that the indirect effect is stronger (vs. weaker) when the } \\
\text { valence of the norm pertaining to non-overpackaged products is } \\
\text { positive (vs. negative). }\end{array}$ & Supported \\
\hline H4. & $\begin{array}{l}\text { The presence of an endorser has a positive influence on (a) ad } \\
\text { credibility and (b) intention to purchase non-overpackaged } \\
\text { products. }\end{array}$ & $\begin{array}{l}\mathrm{H} 4 \mathrm{a} \text { is rejected } \\
\mathrm{H} 4 \mathrm{~b} \text { is supported }\end{array}$ \\
\hline H5. & $\begin{array}{l}\text { Age similarity between an endorser's profile and the target } \\
\text { public profile positively influences (a) ad credibility and (b) } \\
\text { intention to purchase non-overpackaged products through the } \\
\text { mediator effect of identification with the endorser. }\end{array}$ & Supported \\
\hline H6. & $\begin{array}{l}\text { (a) Ad credibility and (b) intention to purchase non- } \\
\text { overpackaged products are higher (vs. lower) when the } \\
\text { testimonial comes from a celebrity connected with the } \\
\text { environmental issue than when the testimonial comes from a } \\
\text { non-connected celebrity or a typical consumer. }\end{array}$ & $\begin{array}{l}\text { H6a is supported } \\
\text { H6b is rejected }\end{array}$ \\
\hline
\end{tabular}




\section{Appendix 1. Examples of stimuli used in Study 2}

\begin{tabular}{|c|c|c|}
\hline $\begin{array}{l}\text { La majorité des Français ont considérablement réduit } \\
\text { leur volume de déchets ménagers ces dernières } \\
\text { années. } \\
\text { Cette réduction est essentiellement due à la volonté } \\
\text { croissante de privilégier des produits avec moins } \\
\text { d'emballages. (1) }\end{array}$ & $\begin{array}{l}\text { La majorité des Français ont considérablement réduit } \\
\text { leur volume de déchets ménagers ces dernières } \\
\text { années. } \\
\begin{array}{l}\text { Cette réduction est essentiellement due à la volonté } \\
\text { croissante de privilégier des produits avec moins } \\
\text { d'emballages. (1) }\end{array}\end{array}$ & $\begin{array}{l}\text { (1) Did you know it? } \\
\text { Most French people have } \\
\text { significantly reduced their } \\
\text { volume of household waste in } \\
\text { recent years. This reduction is } \\
\text { mainly due to the growing } \\
\text { desire to favor products with } \\
\text { less packaging. } \\
\text { (2) Focus on... } \\
\text { Be careful not to confuse the } \\
\text { different types of packaging } \\
\text { Secondary packaging is used to } \\
\text { group several units of the same } \\
\text { product } \\
\text { Over-packaging surrounds the } \\
\text { product but does not serve to } \\
\text { group several units because they } \\
\text { are already held together (for } \\
\text { example by heat sealing) } \\
\text { (3) Stop overpackaging } \\
\text { (4) "More and more often, I try } \\
\text { to be careful about what I buy... } \\
\text { I avoid overpackaged products } \\
\text { as much as possible". Julien, } 22 \\
\text { years-old, student } \\
\text { (5) "More and more often, I try } \\
\text { to be careful about what I buy... } \\
\text { I avoid overpackaged products } \\
\text { as much as possible". Hervé, } 67 \\
\text { years-old, retired }\end{array}$ \\
\hline
\end{tabular}


1 http://www.casuffitlegachis.fr/particuliers/je-m-informe Accessed 10 September 2017. 